This article was downloaded by: [Australian National University Library]

On: 3 February 2010

Access details: Access Details: [subscription number 907447645]

Publisher Routledge

Informa Ltd Registered in England and Wales Registered Number: 1072954 Registered office: Mortimer House, 3741 Mortimer Street, London W1T 3JH, UK

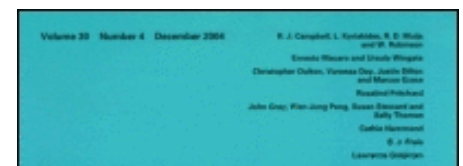

\title{
Oxford Review of Education
}

Publication details, including instructions for authors and subscription information:

http://www.informaworld.com/smpp/title content=t713440173

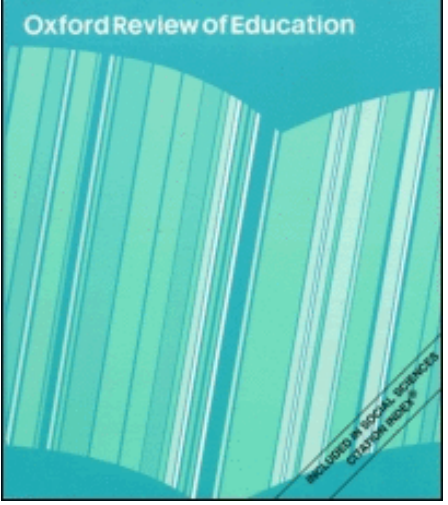

\section{Education as a mechanism for conflict resolution in Northern Ireland}

Bernadette C. Hayes ${ }^{\text {a; }}$ Ian McAllister ${ }^{\mathrm{b}}$

${ }^{a}$ University of Aberdeen, $\mathrm{UK}^{\mathrm{b}}$ Australian National University, Canberra

To cite this Article Hayes, Bernadette C. and McAllister, Ian(2009) 'Education as a mechanism for conflict resolution in Northern Ireland', Oxford Review of Education, 35: 4, 437 - 450

To link to this Article: DOI: $10.1080 / 03054980902957796$

URL: http://dx.doi.org/10.1080/03054980902957796

\section{PLEASE SCROLL DOWN FOR ARTICLE}

\footnotetext{
Full terms and conditions of use: http://www.informaworld.com/terms-and-conditions-of-access.pdf

This article may be used for research, teaching and private study purposes. Any substantial or systematic reproduction, re-distribution, re-selling, loan or sub-licensing, systematic supply or distribution in any form to anyone is expressly forbidden.

The publisher does not give any warranty express or implied or make any representation that the contents will be complete or accurate or up to date. The accuracy of any instructions, formulae and drug doses should be independently verified with primary sources. The publisher shall not be liable for any loss, actions, claims, proceedings, demand or costs or damages whatsoever or howsoever caused arising directly or indirectly in connection with or arising out of the use of this material.
} 


\title{
Education as a mechanism for conflict resolution in Northern Ireland
}

\author{
Bernadette C. Hayes ${ }^{\mathrm{a} *}$ and Ian McAllister ${ }^{\mathrm{b}}$ \\ ${ }^{\mathrm{a} U n i v e r s i t y ~ o f ~ A b e r d e e n, ~ U K ; ~}{ }^{\mathrm{b}}$ Australian National University, Canberra
}

\begin{abstract}
How education systems operate in divided societies is an increasingly important question for academics and educational practitioners as well as for governments. The question is particularly pertinent in post-conflict societies, where education is a key mechanism for resolving conflict between divided communities. Using Northern Ireland as a case study, this article sheds new light on the role of education in conflict resolution by examining the long-term impact of segregated and integrated education on attitudes towards community relations and levels of contact between the Protestant and Catholic communities. The results suggest that individuals who had attended an integrated school are significantly more likely to have friends and neighbours from across the religious divide and that these friendship networks translate into a more optimistic view of future community relations. This is not the case, however, when kinship networks are considered. The evidence from Northern Ireland suggests that the education system can be a source of both conflict and cohesion depending on the nature of the school system as well as the particular source of division to be addressed.
\end{abstract}

\section{Introduction}

In 1998 a historic agreement - the Belfast or Good Friday Agreement-formed the basis of a negotiated peace accord and offered the prospect of political progress in Northern Ireland. However, since then, division and uncertainty have plagued the Agreement and the institutions it created. Despite the efforts of its designers to enhance the centre ground, the post-Agreement period has witnessed increased political polarisation, with the extreme political parties-Sinn Fein (SF) and the Democratic Unionist Party (DUP) - achieving electoral dominance within their respective communities (see Hayes et al., 2005). Furthermore, Northern Ireland remains mired in low but sustained levels of communal violence, increasing rates of social segregation, and widespread public disaffection with the peace accord. Commentators have even suggested that since 1998, Northern Ireland has become a

*Corresponding author. Department of Sociology, University of Aberdeen, Aberdeen AB24 3QY, Scotland. Email: b.hayes@abdn.ac.uk 
more, not less, polarised society (see Hughes \& Donnelly, 2002, 2003; Hayes et al., 2005). By any standards, Northern Ireland's 'peace' is extremely fragile.

To promote reconciliation, academics and policy makers have again focused on the role of the education system in both perpetuating and ameliorating social and political divisions. Although education has traditionally been seen as an institution which reflects social differences, more recent interpretations see it as a mechanism for social change, by identifying the sources of conflict and developing strategies to ameliorate them. In fact, the education system has now moved centre-stage as a core component in the reconstruction of post-conflict and post-genocide societies. Moreover, educational reconstruction is now viewed as crucial for the economic stability that underpins successful reconciliation. As a recent study by the World Bank (2005, p. 27) put it: 'education has a critical role to play in the wider reconstruction of the society, from building peace and social cohesion to facilitating economic recovery and getting the country onto an accelerated development track.'

Nevertheless, the role of education in promoting social cohesion in post-conflict societies is both controversial and contested. Although it has often been assumed that increased education decreases the propensity of individuals to engage in conflict, more recent research questions this assumption (see, Bush \& Saltarelli, 2000; Smith \& Vaux, 2003; Davies, 2004). For example, Davies, in a comprehensive review of the issue, suggests that even in non-post-conflict societies not only does education contribute more to the underlying cause of conflict than it does to peace but a key issue is its magnification of 'ethnic and religious segregation or intolerance' (Davies, 2004, p. 203). A recent UNICEF study lends support to this view (see Bush \& Saltarelli, 2000), by highlighting the use of education as a weapon in the cultural repression of minorities, the denial of education as a weapon in war, and the use of a segregated education system to maintain social inequality. Later research commissioned by the UK Department for International Development reconfirms this view. While stressing that education is an essential tool for human development, it also points to the role of education in both causing and perpetuating conflict, especially within segregated education systems based on religion (Smith \& Vaux, 2003, pp. 30-31).

Although the role of the education system in perpetuating the Northern Ireland conflict has a long and controversial history (Smith, 2001), to date the research has been sparse and inconclusive and has been confined almost exclusively to the schoolage population (see McGlynn et al., 2004, for a review). And, while several studies have stressed the positive benefits of formally integrated schools in promoting crosscommunity friendships, other studies remain ambiguous, suggesting that it has little or no impact. Commentators even suggest that rather than weakening divisive and rigid views, integrated education may in fact reinforce them. More recent research focusing on the long-term impact of integrated education on the adult population questions these pessimistic findings. Hayes et al. (2007) found that individuals who had attended either a formally or informally integrated school were significantly more likely than their religiously-segregated counterparts to occupy the centre ground in identity politics and to disavow bi-partisan territorial allegiances. 
A similar lack of consensus emerges with regard to the impact of segregated schooling on communal divisions. While many observers have long pointed to its potential harmful effects on community relations (see Darby, 1976; Murray, 1985), religious authorities, most notably the Catholic Church, remain unconvinced. Not only does the Catholic hierarchy in Northern Ireland strongly support segregated schools but it also suggests that they are just as well placed as integrated schools to promote reconciliation (Catholic Bishops of Ireland, 2001). Recent government initiatives remain somewhat sceptical of this view. A Shared Future, the most recent strategy for improving community relations in Northern Ireland, while acknowledging the important contribution that both denominational and integrated schools can play in preparing children for their roles as adults in a shared society, also stresses the need for denominational schools to engage across institutional boundaries and develop pro-actively opportunities for shared and inter-cultural education at all levels within society, or what it referred to as the promotion of integrated education in its widest sense (see $A$ Shared Future, OFMDFM, 2005 for a detailed discussion of this issue). A later independent review of the proposals came to the same conclusion (see Schools for the Future, Bain, 2006).

Current national and international policies thus place increasing emphasis on the education system as a potential mechanism for ameliorating social divisions in postconflict societies. This article tests these assumptions by examining the impact of the type of education system - integrated versus segregated —on community relations in Northern Ireland. Using a pooled sample of surveys conducted among the adult population in Northern Ireland between 1998 and 2006, we address for the first time whether or not the type of school system attended has a significant long-term and differential impact on community relations within this society.

The use of Northern Ireland as a case study to investigate this issue is particularly appropriate, for two reasons. First, although the key characteristic of education in Northern Ireland is two religiously-based school systems, in recent years this has shown signs of erosion. Currently, there is a small but growing integrated educational sector, accounting for just $6 \%$ of the school population (DENI, 2007) and attracting students from across the religious and social spectrum (see Gallagher et al., 2003). In addition, there is also a small minority of students, predominantly from a Catholic background, who cross the religious divide and attend a segregated school different to their own religion, which may be considered a 'religiously mixed' school (DENI, 2007). Nevertheless, segregated education remains the dominant position; current government statistics show that $92 \%$ of Protestant children attend a Protestantcontrolled or state school, while $91 \%$ of Catholic children attend a maintained or voluntary Catholic school (DENI, 2007).

Second, although educational segregation based on religion is hardly unique to Northern Ireland, it has particular resonance there. Northern Ireland remains a deeply divided society; not only are Protestants and Catholics educated separately, but they are also segregated both residentially and in their workplaces, and display low levels of religious mobility and intermarriage (Breen \& Hayes, 1996; Breen \& Devine, 1999; Hughes et al., 2006). So great is the level of polarisation and the 
deliberate avoidance of any interaction with the other religious community that for many people they will have little or no contact with a member of the opposing religious tradition prior to attending university or entering the workforce. It is for these two reasons - the differing types of education systems plus the absence of any inter-communal contact - that an investigation of this issue within Northern Ireland is particularly appropriate.

\section{Data and methods}

The data used in the analysis are based on a pooled sample of the 1998 to 2006 Northern Ireland Life and Times Surveys and the 1998 and 2003 Northern Ireland Election Surveys. The 1998-2006 Northern Ireland Life and Times Surveys are nationally representative surveys of the Northern Ireland population conducted in the autumn of each year, based on a random sample of the adult population aged 18 years or over. The 1998 Referendum and Election Survey was a nationally representative post-election survey of all adults aged 18 years or older conducted immediately after the Northern Ireland Assembly elections in June 1998, while the 2003 Northern Ireland Election Study was a nationally representative post-election survey of all adults aged 18 years or older conducted immediately after the Northern Ireland Assembly elections in November 2003. All of the surveys are based on personal interviews. Given our research question, only individuals who explicitly identified themselves as members of the Protestant and Catholic religious communities are included in the analyses. This accounted for 15,302 individuals, or $88 \%$ of the total pooled sample and $99.8 \%$ of those who explicitly claimed a religious affiliation.

Our main independent variable is the type of school the person attended, measured by the question: 'Did you ever attend a mixed school or integrated school in Northern Ireland, that is, a school with fairly large numbers of both Catholic and Protestant children?' The response categories are yes or no. Individuals who said yes were then asked, 'Was this a formally integrated school or was it a school that was just fairly mixed?' Using these two questions, three groups are distinguished in the analysis: individuals who reported attending an integrated school that was a formally integrated school; individuals who reported attending an integrated school that was just fairly mixed; and individuals who said that they had not attended either a mixed school or integrated school in Northern Ireland, or respondents who answered no to the first question. Our sample is based on 15,214 respondents, $1.6 \%$ who said they attended a formally integrated school, $10.4 \%$ who said that it was 'fairly mixed' and $88 \%$ who reported a segregated education.

An important limitation of this categorisation is that we do not know on what numerical basis the respondents evaluated the religious composition of the 'fairly mixed' schools. While it could be argued that this measure has limited utility, it does have value in identifying the proportion of the population who had experience of meeting children of the opposite religion at school, albeit not in a formally integrated context. Also, as we noted earlier, because Catholic children are more likely than Protestant children to cross the religious divide and attend a segregated school 
different to their own religion, we can correctly assume that the vast majority of these informally integrated, or just fairly mixed, schools are, in fact, Protestant schools with a significant Catholic minority.

The two dependent variables are level of contact between the two main religious communities-Protestant and Catholic - and attitudes towards future community relations within this society. Three dimensions of community contact are investigated: friendship and kinship patterns as well as residential location. Each of the dimensions are operationalised in terms of the following three separate questions: 'About how many of your friends would you say are the same religion as you?'; 'What about your relatives, including relatives by marriage? About how many are the same religion as you?'; and 'What about your neighbours? And about how many are the same religion as you?' In all three cases, the response categories were: All, most, half, less than half, or none. Attitudes towards future community relations were operationalised in terms of the following question: 'Do you think that relations between Protestants and Catholics will be better than now, worse than now, or about the same as now in 5 years?' In addition to religious denomination, we also include several socio-demographic measures as control variables in the multivariate models, given previous research as to their significant association with levels of community contact and attitudes towards community relations (see Hayes \& McAllister, 2004).

One caveat concerning our results is the inability to determine causality. Since our results are based on aggregated cross-sectional surveys, we do not know the outlooks of the respondents or their parents before they entered an integrated school. For example, it could be argued that more liberally-minded parents are more likely to send their children to integrated schools, and that the effects we attribute to schooling may in fact be due to selectivity among parents. Research in both the United States and Northern Ireland casts doubt upon this interpretation. Our arguments in support of this proposition are threefold.

First, previous experimental research in the United States demonstrates that contact can and does affect attitudes (Cook, 1978). Second, we know from analyses that have estimated the causal effects from cross-sectional data that the path from contact to attitudes tends to be stronger than the reciprocal path (Pettigrew, 1977). In fact, there is now a growing and converging body of studies-longitudinal, experimental and meta-analytic - to suggest that intergroup contact can significantly affect attitudes, including a reduction in prejudice (see Tropp \& Pettigrew, 2005, p. 951). Third, at least as far as Northern Ireland is concerned, there is empirical evidence to suggest that contact between the two religious communities in an integrated educational setting also affects attitudes. Previous research demonstrates that not only are pupils in integrated schools drawn from both religious traditions as well as a variety of social backgrounds (Gallagher et al., 2003) but they attract children who had little or no contact with the 'other side' prior to an integrated education, suggesting that it is the school environment and not parental influence which promotes this more integrationist position (see McGlynn, 2003, pp. 11-28).

Data from the 2006 Northern Ireland Life and Times survey further support this view, although caution should be applied in interpreting the findings given the 
extremely small number of individuals involved. For example, when those who said that they had attended a formally integrated school were questioned about the amount of contact they had with the other religious community prior to their attendance at their first integrated school, just under two-thirds reported little or hardly any prior contact. This issue of causality, however, can only be comprehensively resolved by extensive, long-term panel studies which are currently unavailable.

\section{Inter-community contact}

Does the education system influence the level of community contact? In other words, are individuals who experienced integrated education different in their behaviour from those who attended a segregated school? Table 1 addresses this question by focusing on the relationship between type of school attended and the extent of social contact between the two religious communities via kinship and friendship patterns as well as residential location. The results provide support for the role of integrated schools in undermining social division, and demonstrate the long-term effects of integrated schooling in promoting a more integrationist outlook. In two of the three networks considered-friendship and residential location-statistically significant differences emerge in terms of the level of contact between the two religious communities in relation to those who had attended a segregated school versus those who had not. These differences are particularly pronounced in the case of friendship patterns.

Table 1. Type of school and social contact between the two religious communities

\begin{tabular}{lccc}
\hline & \multicolumn{3}{c}{ (Per cent of the same religion) } \\
\cline { 2 - 4 } & Integrated & Fairly Mixed & Segregated \\
\hline Friends: & 43.5 & 50.7 & 69.1 \\
All/most & 42.4 & 42.6 & 26.1 \\
Half & 14.1 & 6.6 & 4.8 \\
Less than half/none & $(85)$ & $(467)$ & $(3,910)$ \\
(N) & & & \\
Neighbours: & 51.8 & 58.9 & 71.7 \\
All/Most & 26.8 & 31.0 & 8.3 \\
Half & 21.4 & 10.1 & $(2,331)$ \\
Less than half/none & $(56)$ & $(287)$ & 86.4 \\
(N) & & & 8.1 \\
Relatives: & 79.2 & 83.7 & 5.5 \\
All/most & 12.5 & 10.6 & $(3,314)$ \\
Half & 8.3 & 5.7 & \\
Less than half/none & $(72)$ & $(424)$ & \\
(N) & & & \\
\hline
\end{tabular}

Sources: Pooled file of the Northern Ireland Life and Times Survey, 1998-2006; Northern Ireland Referendum and Election Survey, 1998; Northern Ireland Election Study, 2003 
The results in Table 1 show that around seven out of every ten adults who had experienced a segregated education reported that 'most' or 'all' of their friends were from their own religion. This compares with much lower proportions among those educated in a non-segregated setting, notably among those educated in formally integrated schools. While just over half of those educated in a 'fairly mixed' school claimed that 'most' or 'all' of their friends were from their own religion, the equivalent proportion among the formally integrated was lower still at just $44 \%$. A similar pattern emerges with regard to actual levels of contact between the two main religious communities; just $5 \%$ of those who had experienced a segregated education claimed to have 'less than half' or 'no' friends of the same religion, compared to $7 \%$ and $14 \%$ among those educated in either an informally or formally integrated educational setting, respectively.

There are similar findings with respect to residential location in that individuals who had experienced a formally integrated education are the least religiously exclusive in their living arrangements. For example, while seven out of every ten adults who had experienced a segregated education reported that 'most' or 'all' of their neighbours were from their own religion, the equivalent proportions among those who had either experienced a fairly mixed or formally integrated educational background were considerably lower at just 59\% and 52\%, respectively. Thus, at least as far as friendship patterns and geographical location are concerned, the results are clear. Individuals who had attended a non-segregated school are much less religiously exclusive in terms of both their friendship and residential patterns than those who had attended a segregated one.

This is not the case when intermarriage patterns or the number of relatives from a different religious background are considered. The most striking finding in Table 1 is the lack of contact between the communities in their choice of marriage partners. Irrespective of school background, eight out of every ten adults say that 'most' or 'all' of their relatives are from their own religion. Although there is some impact for the type of education system, the effects in general are small, certainly compared to the previous results on friendship and residence. This finding confirms earlier research with regard to the central role of endogamy in perpetuating communal divisions (see Harris, 1972; Moxon-Browne, 1991).

One important caveat to these results is the non-voluntary nature of this social contact measure. Briefly put, whereas a person can choose neighbours and friends, this does not apply to relatives. It is this factor-the involuntary nature of kinship groups and its potential deflationary impact on contact levels between the two religious communities - which may account for the lack of association between school type and social contact.

Multivariate analysis supports these findings (see Table 2). When a range of background variables, including religion, were taken into account, individuals who had experienced either a formally integrated or fairly mixed educational background were significantly more likely to cross the religious divide and have friends or neighbours from a different religious background from their own. Furthermore, there is a greater propensity for cross-community contact in both friendship and residential 
Table 2. The impact of type of school on social contact between the two religious communities (multivariate results)

\begin{tabular}{|c|c|c|c|c|c|c|}
\hline & \multicolumn{6}{|c|}{ (Logistic Regression Coefficients) } \\
\hline & \multicolumn{2}{|c|}{ Friends } & \multicolumn{2}{|c|}{ Neighbours } & \multicolumn{2}{|c|}{ Relatives } \\
\hline \multicolumn{7}{|l|}{ Socio-demographic controls: } \\
\hline Religion (Protestant) & $-0.48 * *$ & $(0.07)$ & $-0.26 * *$ & $(0.09)$ & $-0.55 * *$ & $(0.10)$ \\
\hline Gender (male) & $-0.17^{*}$ & $(0.07)$ & -0.11 & $(0.09)$ & $-0.34 * *$ & $(0.10)$ \\
\hline Church attendance (attends) & $-0.50 * *$ & $(0.09)$ & 0.01 & $(0.12)$ & $-0.77 * *$ & $(0.13)$ \\
\hline Age (years) & $0.01 * *$ & $(0.01)$ & $0.01 * *$ & $(0.01)$ & $0.01^{*}$ & $(0.01)$ \\
\hline \multicolumn{7}{|l|}{ Education: } \\
\hline Tertiary & $0.38 * *$ & $(0.10)$ & $0.55^{* *}$ & $(0.13)$ & 0.19 & $(0.14)$ \\
\hline Secondary & $0.31 * *$ & $(0.08)$ & $0.26^{*}$ & $(0.11)$ & 0.05 & $(0.12)$ \\
\hline No qualification $^{\mathrm{a}}$ & - & - & - & - & - & - \\
\hline Employment (labour active) & $0.36^{* *}$ & $(0.08)$ & $0.28 * *$ & $(0.10)$ & -0.04 & $(0.11)$ \\
\hline \multicolumn{7}{|l|}{ School Type: } \\
\hline Formally Integrated & $1.03 * *$ & $(0.23)$ & $0.90 * *$ & $(0.28)$ & 0.43 & $(0.32)$ \\
\hline Fairly Mixed & $0.76^{* *}$ & $(0.10)$ & $0.57 * *$ & $(0.13)$ & 0.22 & $(0.15)$ \\
\hline Segregated $^{\mathrm{a}}$ & - & - & - & - & - & - \\
\hline Constant & \multicolumn{2}{|c|}{-0.78} & \multicolumn{2}{|c|}{$-1.54^{*}$} & \multicolumn{2}{|c|}{$-1.32 * *$} \\
\hline $\begin{array}{l}\text { Nagelkerke R square } \\
\text { (N) }\end{array}$ & \multicolumn{2}{|c|}{$\begin{array}{c}0.06 \\
(4,368)\end{array}$} & \multicolumn{2}{|c|}{$\begin{array}{c}0.04 \\
(2.618)\end{array}$} & \multicolumn{2}{|c|}{$\begin{array}{l}0.03 \\
(3,704)\end{array}$} \\
\hline
\end{tabular}

Note: The dependent variable is coded 1 (at least half not of the same religion) and 0 (more than half of the same religion); Standard errors are in parentheses; ${ }^{a}=$ omitted category of comparison, $*=$ statistically significant at $\mathrm{p}<.05, * *=\mathrm{p}<.01$

Sources: As for Table 1

patterns among those who had experienced a formally integrated education as compared to those with an informally integrated one. This was not the case when inter-marriage patterns, or the number of relatives from a dissimilar religious background, were considered. Here, no statistically significant differences emerged between type of school attended and the level of contact between the two religious communities. Rather, the key predictor of cross-community contact is religious background. Both Protestants and the religiously committed are significantly less likely than their Catholic and less church-going counterparts to cross the religious divide in terms of their choice of marital partner. This is not an unexpected finding given the long tradition and expectations of a Catholic conversion by the Protestant partner in religiously-mixed marriages (Fulton, 2002).

In summary, then, individuals who had attended an integrated school are significantly more likely to have friends and neighbours from across the religious divide than those who attended a segregated school. Furthermore, with regard to friendship networks and residential patterns, it is attendance at a formally integrated school which stands out as the most important predictor of cross-community contact. This is not the case, however, with respect to kinship patterns. Here, 
irrespective of school background, religious exclusivity is by far the dominant pattern. These findings reinforce earlier studies which have highlighted the crucial importance of kinship ties in maintaining religious divisions (see White, 1990). Although there has been an increase in mixed marriages - it remained around 5\% from the 1960s through to the 1980s (Rose, 1971; Moxon-Browne, 1991) and has now doubled to around $10 \%$-the expansion of integrated education has not contributed to this increase.

\section{Community contact and community relations}

Are individuals who have experienced a non-segregated education more optimistic in their attitudes towards community relations as compared to those who have attended a segregated school? Table 3 addresses this question by focusing on the relationship between type of school attended and attitudes towards future community relations. The results provide support for the differential effects of school type, and demonstrate the long-term effects of integrated schooling in promoting positive community relations. While around six out of every ten adults who had experienced a formally integrated education reported that they expected relations between the two main religious communities to be 'better' in about five years time, among those educated in either an informally integrated or segregated setting just over half voiced this opinion. A similar, albeit converse, pattern emerges when the opposing view is considered; just 3\% of those who had experienced a formally integrated education believed community relations would get 'worse', compared to $7 \%$ and $8 \%$ among those educated in either an informally integrated or segregated educational setting, respectively.

Similar findings emerge when the relationship between current levels of contact between the two religious communities and attitudes towards future community relations are considered. The results in Table 4 show that, irrespective of the nature of the contact, individuals with cross-community networks are notably more positive in their attitudes and this is particularly the case when cross-community friendship patterns are considered. For example $35 \%$ of individuals whose friends were exclusively drawn from the same religion believed that community relations would be better in five years, compared to the $55 \%$ among those where only half their friends

Table 3. Type of school and future community relations

\begin{tabular}{lccc}
\hline & \multicolumn{3}{c}{ (Percentages) } \\
\cline { 2 - 4 } & Integrated & Fairly Mixed & Segregated \\
\hline Better & 60.6 & 53.4 & 51.7 \\
About the same & 36.2 & 39.7 & 40.8 \\
Worse & 3.2 & 6.8 & 7.5 \\
$(\mathrm{~N})$ & $(221)$ & $(1,452)$ & $(12,258)$ \\
\hline
\end{tabular}


Table 4. Social contact and future community relations

\begin{tabular}{lccc}
\hline & \multicolumn{3}{c}{ (Per cent who think relations will be better) } \\
\cline { 2 - 4 } Same religion & Friends & Neighbours & Relatives \\
\hline All & 35.0 & 43.9 & 43.5 \\
Most & 48.2 & 50.7 & 53.5 \\
Half & 54.8 & 51.9 & 56.9 \\
Less than half/none & 52.4 & 49.8 & 50.4 \\
(Base N) & $(3,602)$ & $(2,770)$ & $(3,434)$ \\
\hline
\end{tabular}

Sources: As for Table 1

were co-religionists. There are similar findings with respect to kinship patterns and residential location in that it is again individuals with religiously exclusive networks who stand out as the least positive in their views.

Multivariate analysis again supports these findings (see Table 5). For the purpose of this investigation, two models have been estimated. Model 1 which shows the impact of type of school on attitudes towards future community relations, net of a range of socio-demographic background factors, and Model 2, which includes the additional mediating effect of level of contact between the two main religious communities. Focusing on Model 1, the results suggest that even when a range of background variables were taken into account, it is individuals who had experienced a formally integrated educational background who stand out as the most positive in their views. As a group, individuals who had attended a formally integrated school were significantly more likely than their previously segregated counterparts (the omitted category of comparison) to hold a more optimistic opinion concerning future relations in Northern Ireland. This is not the case in relation to those attending an informally integrated school, which has no significant impact on attitudes.

The impact of integrated education on attitudes to future community relations is mediated by the level of cross-community contact. As the results in Model 2 demonstrate, once the effects of levels of contact between the two main religious communities are included in the model, type of school fails to emerge as a significant predictor of attitudes. Of these various contact measures, however, only friendship patterns emerge as a significant determinant of views. In confirmation of our earlier bivariate analysis, individuals with cross-community friendship networks are more positive toward future community relations than their religiously exclusive counterparts. Other factors are also important; educated individuals are significantly more likely to hold a more optimistic view of future relations between the two communities than their less-qualified counterparts.

In summary, individuals who had attended an integrated school are significantly more likely to be optimistic about future relations between the two religious communities in Northern Ireland. Furthermore, this relationship between type of school attended and future community relations is mediated by the level of cross-community contact. Thus, individuals who have experienced an integrated education can be seen 
Table 5. The impact of type of school and social contact on future community relations (multivariate results)

\begin{tabular}{|c|c|c|c|c|}
\hline & \multicolumn{4}{|c|}{ (Logistic Regression Coefficients) } \\
\hline & \multicolumn{2}{|c|}{ Model 1} & \multicolumn{2}{|c|}{ Model 2} \\
\hline \multicolumn{5}{|l|}{ Socio-demographic controls: } \\
\hline Religion (Protestant) & $-0.63 * *$ & $(0.04)$ & $-0.61 * *$ & $(0.09)$ \\
\hline Gender (male) & 0.06 & $(0.04)$ & 0.11 & $(0.09)$ \\
\hline Church attendance (attends) & $0.16^{* *}$ & $(0.05)$ & 0.05 & $(0.12)$ \\
\hline Age (years) & $0.01 * *$ & $(0.01)$ & 0.01 & $(0.01)$ \\
\hline \multicolumn{5}{|l|}{ Education: } \\
\hline Tertiary & $0.59 * *$ & $(0.06)$ & $0.74^{* *}$ & $(0.13)$ \\
\hline Secondary & $0.32 * *$ & $(0.04)$ & $0.34^{* *}$ & $(0.11)$ \\
\hline No qualification $^{\mathrm{a}}$ & - & - & - & - \\
\hline Employment (labour active) & $0.13^{* *}$ & $(0.04)$ & -0.14 & $(0.10)$ \\
\hline \multicolumn{5}{|l|}{ Contact Levels: } \\
\hline Friends (high) & - & - & $0.30 * *$ & $(0.06)$ \\
\hline Neighbours (high) & - & - & -0.07 & $(0.05)$ \\
\hline Relatives (high) & - & - & 0.07 & $(0.06)$ \\
\hline \multicolumn{5}{|l|}{ School Type: } \\
\hline Formally Integrated & $0.34^{*}$ & $(0.14)$ & 0.36 & $(0.31)$ \\
\hline Fairly Mixed & 0.07 & $(0.06)$ & -0.16 & $(0.14)$ \\
\hline Segregated $^{\mathrm{a}}$ & - & - & - & - \\
\hline Constant & \multicolumn{2}{|c|}{$-0.30 * *$} & \multicolumn{2}{|c|}{$-0.58 *$} \\
\hline Nagelkerke R square & \multicolumn{2}{|c|}{0.05} & \multicolumn{2}{|c|}{0.07} \\
\hline$(\mathrm{N})$ & \multicolumn{2}{|c|}{$(2,389)$} & \multicolumn{2}{|c|}{$(2,389)$} \\
\hline
\end{tabular}

Note: The dependent variable is coded 1 (better) and 0 (other); Standard errors are in parentheses; ${ }^{\mathrm{a}}=$ omitted category of comparison, $*=$ statistically significant at $\mathrm{p}<.05, * *=\mathrm{p}<.01$

Sources: As for Table 1

as a latent but positive force within this society. As a group, they are significantly more likely to cross the religious divide, particularly in terms of their friendship networks, and this greater inter-community contact leads them to hold a more positive view about future relations.

\section{Conclusion}

The question of how education systems operate in post-conflict societies has become an increasing area of interest for researchers. In Northern Ireland, the respite from the political violence has again brought the role of the education system in perpetuating social and political divisions into sharp relief. A quarter of a century after the first integrated college was established, there remains little research on the possible long-term effectiveness of the type of education system in reducing or perpetuating conflict. While the results of this study cannot provide a definitive answer to this 
question, they do suggest that education, via attendance at a formally integrated school, has positive long-term benefits in promoting a less isolationist stance in relation to inter-community contact and a more optimistic view of community relations.

Our evidence in support of this proposition is fourfold. First, individuals who had attended an informally or formally integrated school were more likely than those who had not to have greater social contact across the religious divide. This relationship remained even after a range of variables were controlled for in the analysis. Second, with respect to friendship networks and residential patterns as well as attitudes towards future relations, it is attendance at a formally integrated school as compared to one that is just fairly mixed that is the most important predictor of crosscommunity contact. Third, these greater levels of cross-community contact among the formally integrated gives rise to a more optimistic view of future community relations. And fourth, our study - based on the adult population - suggests that the positive effects of integrated schooling on social contact networks and their consequent impact on community attitudes extends into later life. As the numbers experiencing integrated schooling grows, these individuals have the potential to break down social barriers and become an important and positive force for change within this society.

Our study has several methodological limitations. First, given the cross-sectional nature of our data, there remains the question of the direction of causality. In the absence of longitudinal data, we cannot provide a definitive answer to this question, however, the weight of academic opinion supports our interpretation, namely, that the experience of integrated schooling leads to less isolationist outlooks. Second, our measures of exposure to integrated education are rudimentary; we do not know for how long individuals attended a formally integrated school and what, if any, particular mechanisms were put in place by teachers and school authorities to foster an 'integrationist' ethos. There are similar limitations in what we know about individuals who attended informally integrated schools. Resolving these methodological limitations and evaluating their consequences for community relations should be a future research priority. This may be considered all the more important in light of new government initiatives to reduce the number of schools and move towards a system of cross-denominational collaboration, or the introduction of integrated education in its widest sense.

As important as an integrated education system appears to be in fostering better community relations in Northern Ireland, it is not the only solution to prejudice and ethnic division. Integrated schooling alone cannot tackle the mutually reinforcing problems of segregation, disadvantage (real and perceived), divergent political aspirations and the pervasive zero-sum mentality that continues to underpin intercommunity relations (Hughes \& Donnelly, 2002; Hayes \& McAllister, 2004; Hughes et al., 2006). Nevertheless, our results suggest that an integrated education system is not only a fruitful place to start but that it should also be a key element within a wider strategy for addressing community divisions-not just in Northern Ireland but in other post-conflict societies. 


\section{Acknowledgements}

Our thanks to Paula Devine for providing us with the combined Northern Ireland Life and Times data set. This article was written while Bernadette C. Hayes was a Visiting Fellow at the Research School of Social Sciences at The Australian National University.

\section{Notes on contributors}

Bernadette C. Hayes is Professor of Sociology and Head of the Department at the University of Aberdeen. She has published widely in the areas of gender, social stratification, health, religion and politics. Her most recent publications include: Conflict and Consensus: A Study of Values and Attitudes in the Republic of Ireland and Northern Ireland (Brill, 2006, co-authored with Tony Fahey and Richard Sinnott) and Integrated Education, Intergroup Relations, and Political Identities in Northern Ireland, Social Problems (2007), 54, 454-482, (co-authored with Ian McAllister and Lizanne Dowds).

Ian McAllister is Professor of Political Science at The Australian National University. $\mathrm{He}$ is the co-author of How Russia Votes (Chatham House, 1998) and The Australian Electoral System (UNSW Press, 2006), and co-editor of The Cambridge Handbook of the Social Sciences in Australia (Cambridge University Press, 2003). He has been director of the Australian Election Study since 1987 and chair of the 50-nation Comparative Study of Electoral Systems since 2003. He is currently working on Australian and comparative electoral behaviour, the Northern Ireland conflict, and patterns of democratisation in post-communist societies.

\section{References}

Bain, G. (2006) Schools for the future: funding, strategy, sharing (Northern Ireland, Department of Education).

Breen, R. \& Hayes, B.C. (1996) Religious mobility in the UK, Fournal of the Royal Statistical Society, Series A, 159, 493-504.

Breen, R. \& Devine, P. (1999) Segmentation and the social structure, in: P. Mitchell \& R. Wilford (Eds), Politics in Northern Ireland (Colorado, Westview Press), 52-65.

Bush, K. D. \& Saltarelli, D. (2000) The two faces of education in ethnic conflict (Florence, UNICEF, Innocenti Research Centre).

Catholic Bishops of Northern Ireland (2001) Building peace, shaping the future (Armagh, Ara Coeli).

Cook, S. W. (1978) Interpersonal and attitudinal outcomes in cooperating interracial groups, Fournal of Research and Development in Education, 12, 97-113.

Darby, J. (1976) Conflict in Northern Ireland: the development of a polarised community (Dublin, Gill \& Macmillan).

Davies, L. (2004) Education and conflict: complexity and chaos (London, RoutledgeFarmer).

Department of Education of Northern Ireland (DENI) (2007) Pupil Religion Series. Available at: http://www.deni.gov.uk/pupil_religion_series-3.xls (accessed 6 November 2007).

Fulton, J. (2002) Religion and enmity in Ireland: institutions and relational beliefs, Social Compass, 49, 189-202. 
Gallagher, T., Smith, A. \& Montgomery, A. (2003) Integrated education in Northern Ireland: participation, profile and performance (Coleraine, UNESCO Centre, University of Ulster)

Harris, R. (1972) Prejudice and intolerance in Ulster: A study of neighbours and strangers in a border community. (Manchester, Manchester University Press).

Hayes, B. C. \& McAllister, I. (2004) Protestant disillusionment with the Northern Ireland Peace Agreement, Irish fournal of Sociology, 13, 109-125.

Hayes, B. C., McAllister, I. \& Dowds, L. (2005) The erosion of consent: Protestant disillusionment with the 1998 Northern Ireland Agreement, fournal of Elections, Public Opinion and Parties, 15, 147-167.

Hayes, B. C., McAllister, I. \& Dowds, L. (2007) Integrated education, intergroup relations, and political identities in Northern Ireland, Social Problems, 54, 454-482.

Hughes, J. \& Donnelly, C. (2002) Ten years of social attitudes to community relations in Northern Ireland in: A.M. Gray, K. Lloyd, P. Devine, G. Robinson \& D. Heenan (Eds) Social attitudes in Northern Ireland: the eight report (London, Pluto Press), 39-55.

Hughes, J. \& Donnelly, C. (2003) Community relations in Northern Ireland: a shift in attitudes, Fournal of Ethnic and Migration Studies, 4, 643-661.

Hughes, J., Campbell, A., Hewstone, M. \& Cairns, E. (2006) Segregation in Northern Ireland: implications for community relations policy. Unpublished paper.

McGlynn, C. (2003) Integrated education in Northern Ireland in the context of critical multiculturalism, Irish Educational Studies, 22, 1-28.

McGlynn, C., Niens, U., Cairns, E. \& Hewstone, M. (2004) Moving out of conflict: the contribution of integrated schools in Northern Ireland to identity, attitudes, forgiveness and reconciliation, Fournal of Peace Education, 1, 147-163.

Moxon-Browne, E. (1991) National identity in Northern Ireland, in: P. Stringer \& G. Robinson (Eds) Social attitudes in Northern Ireland: the $1^{\text {st }}$ report (Belfast, Blackstaff Press), 23-30.

Murray, D. (1985) Worlds apart: segregated schools in Northern Ireland (Belfast, Appletree Press).

Office of the First Minister and Deputy First Minister (OFMDFM) (2005) A shared future (Belfast, Stormont).

Pettigrew, T. F. (1977) Generalized Intergroup contact effects on prejudice, Personality and Social Psychology Bulletin, 23, 173-185.

Rose, R. (1971) Governing without consensus (London, Faber \& Faber).

Smith, A. (2001) Religious segregation and the emergence of integrated schools in Northern Ireland, Oxford Review of Education, 27, 559-575.

Smith, A. \& Vaux, T. (2003) Education, conflict and international development (London, Department for International Development).

Tropp, L. R. \& Pettigrew, T.F. (2005) Relationships between intergroup contact and prejudice among minority and majority status groups, Psychology Science, 16, 951-957.

White, J. (1990) Interpreting Northern Ireland (Oxford, Clarendon Press).

World Bank (2005) Reshaping the future: education and postconflict reconstuction (Washington, DC, World Bank). 